\section{OPEN JOURNAL SYSTEMS}

ISSN:2237-2202
Available on line at Directory of Open Access Journals

Journal of Hyperspectral Remote Sensing v.7, n.6 (2017) 324-333

www.periodicos.ufpe.br/revistas/jhrs
Journal of Hyperspectral Remote Sensing

\title{
Spatial distribution of biophysical parameters in the Ipanema River Basin using remote sensing techniques
}

Jhon L. B. da Silva*, Diego C. dos S. Araújo**, Daniella P. dos Santos ${ }^{* * *}$, Alan C. Bezerra ${ }^{* * * *}$, Geber B. de A. Moura $^{* * * * *}$, Pabrício M. O. Lopes ${ }^{* * * * * *}$ Hernande P. da Silva ${ }^{* * * * * * *}$

* MSc in Agricultural Engineering - Departamento de Engenharia Agrícola, Universidade Federal Rural de Pernambuco - UFRPE. Av. D. Manoel de Medeiros, SN; Dois Irmãos, Recife, Pernambuco, Brasil; CEP: 52171-900. E-mail: jhonlennoigt@ hotmail.com (Corresponding author).

** MSc in Agricultural Engineerin - Departamento de Engenharia Agrícola - UFRPE. E-mail: diego @agro.eng.br

*** MSc in Agricultural Engineerin - Departamento de Engenharia Agrícola - UFRPE. E-mail: daniellapsantos@hotmail.com **** MSc in Agricultural Engineerin; Assistant professor at Universidade Federal Rural de Pernambuco - Unidade Acadêmica de Serra Talhada - UAST/UFRPE, Serra Talhada, Pernambuco, Brasil. E-mail: cezaralan.a@gmail.com ***** Ph.D. in Oceanography; Associate professor at UFRPE. E-mail: geber@depa.ufrpe.br ****** Ph.D. in Remote Sensing; Assistant teacher at UFRPE. E-mail: pabriciope@gmail.com ******* Ph.D. in Soil Science; Professor at UFRPE and at Instituto Federal de Educação, Ciência e Tecnologia de Pernambcuo IFPE, Recife, Pernambuco, Brasil. E-mail: hernandepereira@yahoo.com.br

Received 13 June 2017; accepted 30 October 2017

\begin{abstract}
Remote sensing techniques obtain essential information about the biophysical parameters at the interface earth's surface and atmosphere that are important for observing the vegetation conditions in the different land uses and occupations, especially in survey directed to hydrographic basins. The objective of this study was to evaluate the spatial distribution of biophysical parameters in the Ipanema River basin by remote sensing. An image of Landsat 8 OLI/TIRS satellite was used, on the date of passage November 14, 2015, covering the all study area of Ipanema River basin, located in the Brazilian semiarid region. The image was processed by ERDAS IMAGINE ${ }^{\circledR} 9.1$ Software. Radiometric calibration and conversion to radiance and reflectance were performed with the surface data using the SEBAL algorithm. The meteorological data were collected from an automatic station belonging to INMET, located in the study area. The thematic maps of the biophysical parameters albedo, land surface temperature $\left(\mathrm{T}_{\text {sup }}\right)$ and the radiation balance $\left(R_{n}\right)$ were processed by ArcGIS ${ }^{\circledR}$ 10.2.2 Software. The descriptive statistics were used to determine the differences of these parameters in relation to the local climate of the region and anthropic actions. Radiation balance $\left(\mathrm{R}_{\mathrm{n}}\right)$ was closely related to the albedo spatial patterns and surface temperature. The highest values of $R_{n}$ were represented by the lowest albedo values. The results obtained corroborate with those present in the literature and show spectral behavior typical of targets that integrate the classes of land use and occupation in the semiarid region during the dry season, evidencing that the SEBAL algorithm can be used with great potential for estimation of radiation balance.
\end{abstract}

Key words: albedo, surface temperature, radiation balance, environmental changes, land use.

\section{Introduction}

The advances in remote sensing in recent years have allowed the monitoring of different and large areas of the various biomes in the world, especially the monitoring of the spatial and temporal dynamics of the Caatinga, a semiarid region located in the Brazilian Northeast, which is constantly suffering by anthropic actions and natural changes in the environment. Due to the scarcity of meteorological data, the use of alternative techniques to aid in the complementation of information in these regions is indispensable, especially in the hydrographic basins, which makes possible the hydrological planning (Cunha et al., 2012; Bezerra et al., 2014).

Given the importance and the deficiency of field data to monitor the spatio-temporal dynamics of these regions, remote sensing research allows understanding the behavior of biophysical parameters due to climate changes and the identification of possible changes in land use and occupation in hydrographic basins. However, remote sensing techniques are used to obtain information about surface and atmospheric parameters that are important for the monitoring of flows or other 
associated variables on regional and global scale, whose level of detail is determined by the spatial resolution of the multispectral sensors used. Thus, the monitoring of biophysical parameters, especially albedo, surface temperature and the radiation balance are essential in the decision making regarding environmental aspects in general (Silva et al., 2005; Bezerra et al., 2014).

In the determination of these parameters, vegetation conditions and changes in land use are observed, therefore, their knowledge becomes even more important when directed to studies in basins to obtain information necessary for the management of natural resources in general, preventing environmental imbalances in areas subject to degradation. Albedo and surface temperature are considered some of the most important parameters in studies of climate change, burning, degradation and desertification, that is, in environmental impact studies. Several studies have focused on these aspects in recent years, mainly in the semiarid regions of Brazil (Silva et al., 2005; Silva et al., 2011; Cunha et al., 2012; Oliveira et al., 2012; Bezerra et al., 2014; Oliveira et al., 2015; Silva et al., 2016).

The radiation balance is essential in the soilplant-atmosphere system as it is the main source of energy to be distributed in soil, air and evapotranspiration processes of native vegetation and irrigated areas, and is not usually measured in meteorological stations, since it depends very much on the nature of the surface and therefore suffers great influence of the albedo and surface temperature. However, the assessment of these parameters allows the identification of changes in land use, with important consequences for the environment and climate, especially on a regional scale (Silva et al., 2005; Silva et al., 2011; Bezerra et al., 2014; Oliveira et al., 2015).

Therefore, remote sensing allows the extraction of information from orbital images using algorithms such as SEBAL (Surface Energy Balance Algorithm for Land). SEBAL has high applicability due to its semiautomated process used to estimate the biophysical parameters of the surface energy balance. They are low cost alternatives, with the complementary aid of few surface data. This methodology is observed in constant studies in Brazil and in the world (Bastiaanssen et al., 1998; Bastiaanssen, 2000; Allen et al., 2002; Silva et al., 2005; Silva et al., 2011; Oliveira et al., 2012; Bezerra et al., 2014; Oliveira et al., 2015; Silva et al., 2016).
The choice of the study area was based on the importance of observing the possible environmental alterations from the biophysical indicators that when analyzed allow to assure rapid and effective reversion measures regarding the inadequate management and conservation of the soil and, consequently, to inhibit possible processes of environmental degradation. Thus, this study aimed to quantitatively evaluate the spatial distribution of biophysical parameters obtained through remote sensing products and techniques for the area covered by the Ipanema River Basin, in the states of Pernambuco and Alagoas, Brazil.

\section{Materials and methods}

The Ipanema River basin selected for this research is inserted between the extreme coordinates: $8^{\circ}$ $18^{\prime} 04^{\prime \prime}$; $9^{\circ} 52^{\prime} 24^{\prime \prime} \mathrm{S}$ and $36^{\circ} 36^{\prime} 28^{\prime \prime} ; 37^{\circ} 27^{\prime} 54^{\prime \prime} \mathrm{W}$, covering 34 municipalities, 18 of the state of Alagoas and 16 of the state of Pernambuco (Figure 1). It borders the Ipojuca river basin to the north, the São Francisco River to the south, the Capiá and Moxotó river basins to the west, and the Traipú river basin to the east. The headwaters of the Ipanema River are located in the municipality of Pesqueira, Pernambuco, its course runs through the state of Pernambuco in approximately 139 $\mathrm{km}$ and $87 \mathrm{~km}$ in the state of Alagoas, in a north-south direction, until it flows into the São Francisco River (APAC, 2017).

The study was developed in the dry period for the region. Initially, to perform the image processing, it was necessary to collect surface data from meteorological stations in the area of study belonging to the Pernambuco State Water and Climate Agency (APAC) and the National Meteorological Institute (INMET), located in the municipality of Arcoverde, upstream of the Ipanema River Basin. The data used were: instantaneous air temperature $\left(\right.$ Tair, ${ }^{\circ} \mathrm{C}$ ); relative humidity of the air (RH, \%); atmospheric pressure of the instantaneous air (Po, $\mathrm{kPa})$; average daily global solar radiation (Rs $24 \mathrm{~h}, \mathrm{~W} \mathrm{~m}-2$ ). It should be noted that these data were observed at 10:00 am local time, coinciding with the time of the satellite passage. However, the study was developed from a Landsat 8 satellite image of the OLI/TIRS (Operational Land Imager/Thermal Infrared Sensor) sensors, on the date of passage Nov. 14, 2015, acquired from NASA. 

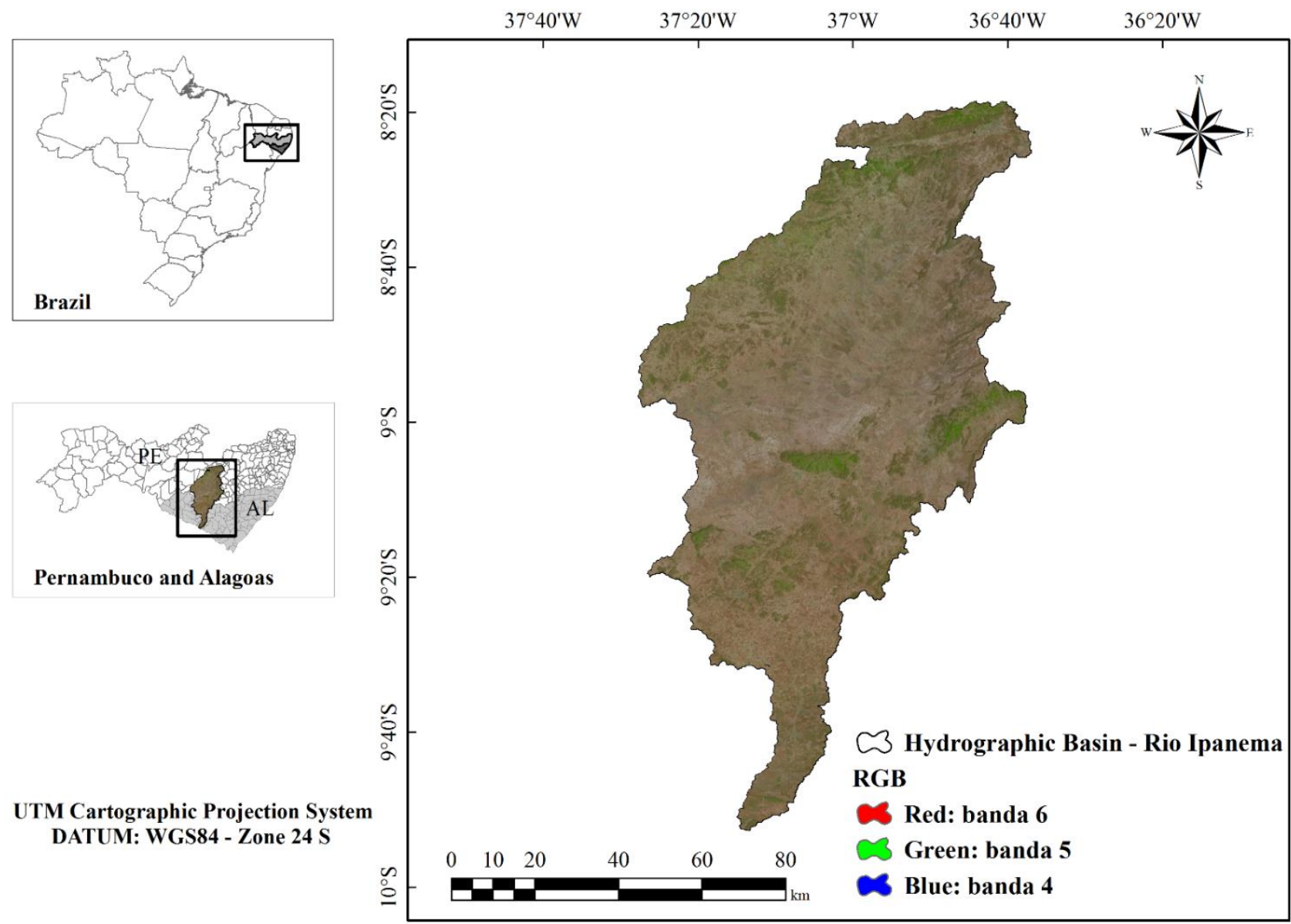

Figure 1 - Spatial location map of the Ipanema River Basin, Landsat 8 satellite image and OLI sensor obtained on November 14, 2015 in the RGB-654 composition.

Thus, ERDAS IMAGINE ${ }^{\circledR}$ Software was used in version 9.1, using the Model Maker tool, the image was processed and the biophysical parameters were estimated. The thematic maps of the parameters albedo, surface temperature and radiation balance were processed by ArcGIS ${ }^{\circledR}$ 10.2.2 Software. Table 1 presents the input data at the time of the satellite passage, such as the sequential day of the year (SDY), local time of passage (h:min.), elevation angle of the Sun (E, degrees), instantaneous temperature of the air $\left(\mathrm{T}_{\mathrm{air}},{ }^{\circ} \mathrm{C}\right)$, instantaneous relative humidity of the air $(\mathrm{RH}, \%)$ and the instantaneous atmospheric pressure of the air $\left(\mathrm{P}_{\mathrm{o}}\right.$, $\mathrm{kPa})$.

Table 1 - Input data and variables at the time the satellite passes through the automatic weather station.

\begin{tabular}{cccccccc}
\hline $\begin{array}{c}\text { Landsat } \\
\text { Satellite }\end{array}$ & $\begin{array}{c}\text { Date of } \\
\text { Image }\end{array}$ & SDY & $\begin{array}{c}\text { Time } \\
(\mathbf{h}: \text { min. })\end{array}$ & $\begin{array}{c}\mathbf{E} \\
(\text { degrees })\end{array}$ & $\begin{array}{c}\mathbf{T}_{\text {air }} \\
\left({ }^{\circ} \mathbf{C}\right)\end{array}$ & $\begin{array}{c}\mathbf{R H} \\
(\boldsymbol{\%})\end{array}$ & $\begin{array}{c}\mathbf{P}_{\mathbf{o}} \\
(\mathbf{k P a})\end{array}$ \\
\hline 8 OLI/TIRS & $11 / 14 / 2015$ & 319 & $09: 36$ & 64.62 & 21 & 92 & 93.01 \\
\hline
\end{tabular}

With the determined image of the Landsat 8 OLI satellite with the bands 2 to 7 , the spectral radiance $\left(\mathrm{L}_{b}\right.$ Land 8) was determined based on the additive and multiplicative terms, as well as the monochromatic reflectance, with which it was necessary to convert the quantized values and calibrated from the gray level of each band of the Landsat 8 OLI sensor system in radiance and reflectance, using radiometric coefficients to determine them using Equations 1 and 2, respectively (Chander e Markham, 2003; Silva et al., 2016). 
$\mathrm{L}_{\mathrm{b} \text { Land 8 }}=\mathrm{Add}_{\mathrm{rad} \mathrm{b}}+$ Mult $_{\mathrm{rad} \mathrm{b}} \cdot \mathrm{ND}_{\mathrm{b}}$

where $\mathrm{L}_{\mathrm{b} \text { Land } 8}\left(\mathrm{~W} \mathrm{~m}^{-2} \mathrm{sr}^{-1} \mu \mathrm{m}^{-1}\right)$ is the spectral radiance of each pixel in each band; $b$ (subscript) represents each of the bands of Landsat $8 \mathrm{OLI}, \operatorname{Add}_{\mathrm{rad}} \mathrm{b}$ is the additive term and Mult rad $_{\mathrm{b}}$ the multiplicative term, related to the radiance, these were extracted from the OLI image metadata. $\mathrm{ND}_{\mathrm{b}}$ is the intensity of each pixel and band (value between 0 and 65365), observed from the study image.

$$
\mathrm{r}_{\mathrm{b} \text { Land } 8}=\frac{\left(\mathrm{Add}_{\mathrm{ref} \mathrm{b}}+\mathrm{Mult}_{\mathrm{ref} \mathrm{b}} \cdot \mathrm{ND}_{\mathrm{b}}\right)}{\cos \theta \cdot \mathrm{d}_{\mathrm{r}}}
$$

Where $r_{b}$ Land $8\left(\mathrm{~W} \mathrm{~m}{ }^{-2} \mathrm{sr}^{-1} \mu \mathrm{m}^{-1}\right)$ is the monochromatic reflectance of each pixel in each OLI band; Add $_{\text {ref }}$ is the term additive and Mult $_{r e f} \mathrm{~b}$ the multiplicative term, relative to the reflectance, also extracted from the metadata of the image; $\theta$ is the solar zenith angle, obtained from the angle of elevation of the sun, contained in the metadata of the image and $d_{r}$ is the inverse of the square of the relative distance Earth-Sun for the day of the image, this was obtained according to Equation 3 (Iqbal, 1983).

$$
\mathrm{d}_{\mathrm{r}}=1+0,033 \cdot \cos \left(\frac{\mathrm{SDY} \cdot 2 \cdot \pi}{365}\right)
$$

where SDY is the sequential day of the year and the argument of the cos function is in radians. The average annual value of $d_{r}$ is generally equal to 1.00 , ranging from about 0.97 to about 1.03 .

The cosine of the solar zenith angle $(\cos \theta$, dimensionless) was obtained from the angle of elevation of the Sun (E, degrees), extracted from the image metadata, according to Equation 4.

$$
\cos \theta=\cos \left(\frac{\pi}{2}-E\right)=\operatorname{sen}(E)
$$

The albedo at the top of the atmosphere $\left(\alpha_{\text {toa }}\right)$, the albedo without correction, was then determined. It consists of a linear combination of the reflectance in each of the Landsat 8 OLI reflective bands, with the respective values of the weights of those bands, which were proposed by Silva et al. (2016): the band 2: 0.300; band 3: 0.277; band 4: 0.233 ; band 5: 0.143 ; band 6: 0.035 e band 7: 0.012 (Equation 5).

$\alpha_{\text {toa }}=0.300 . r_{2}+0.277 . r_{3}+0.233 . r_{4}+0.143$.

$\mathrm{r}_{5}+0.035 \cdot \mathrm{r}_{6}+0,012 . \mathrm{r}_{7}$
The corrected surface albedo was also estimated by means of the previous parameter (Allen et al., 2002; Silva et al., 2005; Oliveira et al., 2012; Silva et al., 2016), according to equation 6.

$$
\alpha_{\text {sup }}=\frac{\alpha_{\text {toa }-} \alpha_{\text {atm }}}{\tau_{\mathrm{sw}}^{2}}
$$

where $\alpha_{\text {sup }}$ is the surface albedo corrected for atmospheric effects; $\alpha_{\mathrm{atm}}$ is the reflectance of the atmosphere itself, the value of 0.03 is recommended, based on studies conducted by several researchers using the same methodology (Bastiaanssen, 2000; Silva et al., 2005; Oliveira et al., 2012; Bezerra et al., 2014; Silva et al., 2016); $\tau_{\mathrm{sw}}$ is the atmospheric transmissivity in the field of solar radiation for days of clear sky, obtained according to Equation 7 (Allen et al., 2002; Allen et al., 2007; Oliveira et al., 2012; Silva et al., 2016).

$\tau_{\mathrm{sw}}=0.35+0.627 . \exp$.

$\left[\frac{-0.00146 \cdot \mathrm{P}_{\mathrm{o}}}{\mathrm{K}_{\mathrm{t}} \cdot \cos \theta}-0.075\left(\frac{\mathrm{W}}{\cos \theta}\right)^{0.4}\right]$

where $P_{o}(\mathrm{kPa})$ is the instantaneous atmospheric pressure (measured in the weather station); $\mathrm{K}_{\mathrm{t}}$ is the turbidity coefficient of the atmosphere, in this study $\mathrm{K}_{\mathrm{t}}$ $=1.0$ (for clear and clean sky) was used, proposed by Allen et al. (2002). This value was also observed in others studies conducted in the Brazilian semiarid region (Oliveira et al., 2012; Silva et al., 2016); W (mm) is the precipitable water obtained as a function of the relative humidity of the instantaneous air (also measured in the meteorological station), this parameter was computed according to Equation 8 (Garrison e Adler 1990).

$\mathrm{W}=0,14 \cdot \mathrm{e}_{\mathrm{a}} \cdot \mathrm{P}_{\mathrm{o}}+2 \cdot 1$

where $e_{a}(\mathrm{kPa})$ is the actual water vapor pressure, calculated by the automatic station meteorological data, according to Equation 9.

$$
\mathrm{e}_{\mathrm{a}}=\frac{\mathrm{UR} \cdot \mathrm{e}_{\mathrm{s}}}{100}
$$

where $e_{s}(\mathrm{kPa})$ is the saturation pressure of the water vapor also obtained by means of meteorological data, Equation 10.

$$
\mathrm{e}_{\mathrm{s}}=0.6108 \cdot \exp \left(\frac{17.27 \cdot \mathrm{T}_{\text {air }}}{237.3+\mathrm{T}_{\text {air }}}\right)
$$


where $\mathrm{T}_{\text {air }}\left({ }^{\circ} \mathrm{C}\right)$ is the instantaneous air temperature.

In order to estimate the biophysical parameters, such as surface temperature and surface radiation balance, the following vegetation indexes were estimated: NDVI, SAVI and LAI for all pixels in the image.

The Normalized Difference Vegetation Index (NDVI) was obtained by the ratio of the difference between the near infrared reflectance ( $\mathrm{r}_{\mathrm{b}}$ IV) and the red $\left(r_{b} v\right)$, by the sum of these, according to Equation 11 (Allen et al., 2002; Silva et al., 2005; Oliveira et al., 2012; Bezerra et al., 2014).

$$
\mathrm{NDVI}=\frac{\mathrm{r}_{\mathrm{b} \text { IV }}-\mathrm{r}_{\mathrm{bV}}}{\mathrm{r}_{\mathrm{b} \text { IV }}+\mathrm{r}_{\mathrm{bV}}}
$$

where $\mathrm{r}_{\mathrm{b}}$ IV and $\mathrm{r}_{\mathrm{b}} \mathrm{v}$, respectively, correspond to Landsat 8 OLI reflective bands 5 and 4 .

The SAVI (Soil Adjusted Vegetation Index) was the next caculated index, determined according to Equation 12 (Allen et al., 2002),

$$
\mathrm{SAVI}=\frac{(1+\mathrm{L}) \cdot\left(\mathrm{r}_{\mathrm{b} \text { IV }}-\mathrm{r}_{\mathrm{bVV}}\right)}{\left(\mathrm{L}+\mathrm{r}_{\mathrm{b} \text { IV }}+\mathrm{r}_{\mathrm{bV}}\right)}
$$

where $\mathrm{L}$ is the soil adjustment constant, which depends on the soil type. The value of 0.1 was used, according to some researches (Allen et al., 2007).

After the SAVI was determined, the Leaf Area Index (LAI, $\mathrm{m}^{2} \mathrm{~m}^{-2}$ ) was estimated, according to Allen et al. (2007), Equation 13.

$$
\mathrm{LAI}=-\frac{\ln \left(\frac{0.69-\mathrm{SAVI}}{0.59}\right)}{0.91}
$$

Through the leaf area index was obtained, according to Allen et al. (2002), the narrow band surface emissivity $\left(\varepsilon_{\mathrm{NB}}\right)$ and the broad band surface emissivity $\left(\varepsilon_{0}\right)$, for NDVI $>0$ and LAI $<3$, according to Equations 14 and 15 .

$$
\begin{aligned}
& \varepsilon_{\mathrm{NB}}=0.97+0.0033 . \mathrm{LAI} \\
& \varepsilon_{0}=0.95+0.01 . \mathrm{LAI}
\end{aligned}
$$

The following conditions were adopted: for pixels with LAI values $\geq 3, \varepsilon_{\mathrm{NB}}=\varepsilon_{0}=0.98$ is considered. For NDVI $<0, \varepsilon_{\mathrm{NB}}=0.99$ and $\varepsilon_{0}=0.985$, according to Allen et al. (2002).

After the emissivity was determined, the surface temperature $\left(\mathrm{T}_{\text {sup }}\right)$, in Kelvin, was obtained from equation 16 (Allen et al., 2002; Oliveira et al., 2012; Bezerra et al., 2014).

$$
\mathrm{T}_{\text {sup }}=\frac{\mathrm{K}_{2}}{\left(\frac{\varepsilon_{\mathrm{NB}} \cdot \mathrm{K}_{1}}{\mathrm{~L}_{\mathrm{b}}}+1\right)}
$$

where $\mathrm{K}_{1}$ and $\mathrm{K}_{2}\left(\mathrm{~W} \mathrm{~m}^{-2} \mathrm{sr}^{-1} \mu \mathrm{m}^{-1}\right)$ are calibration constants of the Landsat 8 TIRS thermal bands (thermal band $10, \mathrm{~L}_{\mathrm{b} 10}, \mathrm{~K}_{1}=774.89$ and $\mathrm{K}_{2}=1321.08 \mathrm{~W} \mathrm{~m}^{-2} \mathrm{sr}^{-1}$ $\left.\mu \mathrm{m}^{-1}\right)$, extracted from the image metadata.

Then, the computation of the longwave radiation emitted by the surface $\left(\mathrm{R}_{\mathrm{ol} \mathrm{emit}} \uparrow, \mathrm{W} \mathrm{m}^{-2}\right)$ for each pixel was determined, the broad band surface emissivity $\left(\varepsilon_{0}\right)$ was considered. The parameter was obtained according to Equation 17 (Allen et al., 2002).

$\mathrm{R}_{\mathrm{ol} \mathrm{emit} \uparrow}=\varepsilon_{0} \cdot \sigma \cdot \mathrm{T}_{\mathrm{s}}^{4}$

where $\sigma$ is the Stefan-Boltzmann constant $(\sigma=5,67 \times 10$ ${ }^{8} \mathrm{~W} \mathrm{~m}^{-2} \mathrm{~K}^{-4}$ ) and $\mathrm{T}_{\text {sup }}$ is the surface temperature, in Kelvin.

The estimation of shortwave radiation incident on the surface $\left(\mathrm{R}_{\text {sol inc } \downarrow}, \mathrm{W} \mathrm{m}^{-2}\right)$, which is the flux of direct and diffuse solar radiation that reaches the earth's surface, for clear sky conditions (Allen et al., 2002; Silva et al., 2005) is given by Equation 18.

$$
\mathrm{R}_{\mathrm{sol} \mathrm{inc} \downarrow}=\mathrm{S} \cdot \cos \theta \cdot \mathrm{d}_{\mathrm{r}} \cdot \tau_{\mathrm{sw}}
$$

where $\mathrm{S}$ is the solar constant $\left(1367 \mathrm{~W} \mathrm{~m}^{-2}\right)$.

Thus, it was also necessary to determine the longwave radiation incident by the atmosphere towards the surface $\left(\mathrm{R}_{\mathrm{ol} \mathrm{atm}}, \mathrm{W} \mathrm{\textrm {m } ^ { - 2 }}\right)$ as a function of the atmospheric emissivity of the air $-\varepsilon_{\mathrm{a}}$ (Allen et al., 2002; Bastiaanssen et al., 2005), according to Equation 19.

$$
\mathrm{R}_{\mathrm{ol} \mathrm{atm} \downarrow}=\varepsilon_{\mathrm{a}} \cdot \sigma \cdot \mathrm{T}_{\mathrm{ar}}^{4}
$$

where $\sigma$ is the Stefan-Boltzmann constant; $\mathrm{T}_{\text {air }}$ is the instantaneous air temperature at the automatic weather station, in Kelvin ( $\left.\mathrm{K}=273.15+\mathrm{T}_{\text {air }}\right)$ and $\varepsilon_{\mathrm{a}}$ is the atmospheric emissivity of air (Equation 20), calculated on the basis of the instantaneous atmospheric transmissivity $\left(\tau_{\mathrm{sw}}\right)$ model.

$\varepsilon_{\mathrm{a}}=0.85 \cdot\left(-\ln \cdot \tau_{\mathrm{sw}}\right)^{0.09}$

As a final part of this study, the balance of instantaneous surface radiation $\left(\mathrm{R}_{\mathrm{n}}, \mathrm{W} \mathrm{m}^{-2}\right)$ was estimated according to several researchers (Allen et al., 
2002; Silva et al., 2005; Oliveira et al., 2015), by Equation 21.

$\mathrm{R}_{\mathrm{n}}=\mathrm{R}_{\text {sol inc } \downarrow} \cdot\left(1-\alpha_{\text {sup }}\right)-\mathrm{R}_{\mathrm{ol} \mathrm{emit} \uparrow}+\mathrm{R}_{\mathrm{ol} \mathrm{atm} \downarrow}-(1-$

$\left.\varepsilon_{0}\right) \cdot \mathrm{R}_{\mathrm{ol} \mathrm{atm} \downarrow}$

where $R_{\text {sol inc } \downarrow}$ is the incident shortwave radiation; $\alpha_{\text {sup }}$ is the corrected albedo of each pixel; $R_{o l}$ atm $\downarrow$ is the longwave radiation emitted by the atmosphere in the direction of each pixel; $R_{\mathrm{ol} \mathrm{emit}}$ is the longwave radiation emitted by each pixel and $\varepsilon_{0}$ is the emissivity of each pixel.

For the organization and analysis of the results, the biophysical parameters were submitted to descriptive statistics, based on the minimum, maximum, mean, median, mode, standard deviation and coefficient of variation, in order to determine the differences of these parameters against the climate locality of the region and also of the anthropic actions.

\section{Results and discussion}

The surface albedo is a parameter that assists in the separation of classes of land use and occupation due to its spatial variation in different surfaces. De acordo com Silva et al. (2011), superfícies com cores claras, lisas e secas apresentam maiores valores de albedo, enquanto que superfícies ásperas e escuras tendem a apresentar valores menos elevados.

In the case of the Ipanema river basin, the albedo ranged from $0.04( \pm 0.06)$ to $0.50( \pm 0.06)$, with an average of 0.25 . Higher values were detected in areas of exposed or sparsely vegetated soil, with presence of sparse vegetation, where the albedo was higher than 0.34 . In the portions marked by the presence of more densified vegetation and greater photosynthetic activity, smaller values were found, varying from 0.04 to 0.19 (Figure 2).

Bezerra et al. (2014), evaluating the surface albedo on the state of Rio Grande do Norte, located in the semiarid region, also observed that portions of exposed soil and Caatinga vegetation during drought tended to express higher surface albedo compared to areas with higher biomass. In the bare soil and sparsely vegetated regions, the albedo presented values from 0.30 to 0.35 , similar to what was detected in the Ipanema River basin. However, on this understanding, the dynamics of the spatial pattern of the surface albedo, is associated with different land uses and especially the heterogeneous vegetation of Caatinga.

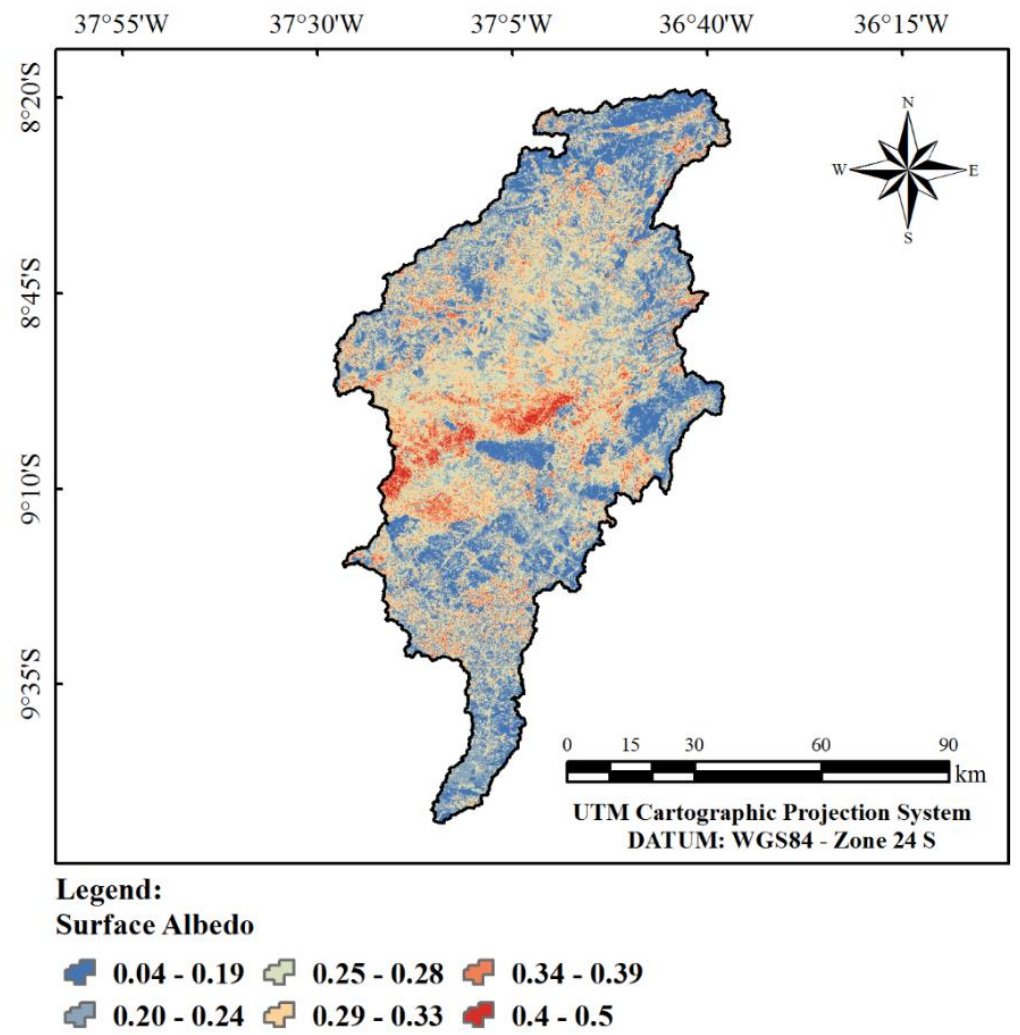

Figure 2 - Thematic map of the spatial distribution of surface albedo (dimensionless) in the Ipanema River Basin on the day of passage of the Landsat 8 (14 November 2015). 
Similarly to albedo, the surface temperature $\left(T_{\text {sup }}\right)$ is also an indicator of the elements that integrate the use and occupation of the soil. In this sense, Bezerra et al. (2014) state that this parameter can be used to identify fire-prone areas and, due to water stress conditions, to detect areas that are more vulnerable to desertification, as well as to provide important information on proper soil and plant management. These $\mathrm{T}_{\text {sup }}$ characteristics are even more important when considering their use in arid and semi-arid regions.

The $\mathrm{T}_{\text {sup }}$, similar to the albedo, presented higher values in areas of exposed or slightly vegetated soil, with values higher than $41.5^{\circ} \mathrm{C}$ in most of the basin. In some points, peaks of $51{ }^{\circ} \mathrm{C}$ were reached, with a general average of $43.02{ }^{\circ} \mathrm{C}$. In contrast, higher and more vegetated areas, as expected, expressed lower $\mathrm{T}_{\text {sup }}$, varying from 26.48 to $35.5{ }^{\circ} \mathrm{C}$ (Figure 3 ).

Cunha et al. (2012) identified similar behavior in a basin of the state of Paraíba, also located in the semiarid region, during dry season. According to the authors, low rainfall indices favor the increase of $\mathrm{T}_{\text {sup }}$, which in the case of the above-mentioned basin, presented maximum averages of $36.4{ }^{\circ} \mathrm{C}$. The lower value in relation to the Ipanema river basin may be due to the climatic characteristics of the region and even the influence of the previous rainfall. It is worth mentioning that no rainfall was recorded within 45 days before the satellite was transferred to the basin evaluated in this study, based on data obtained by National Institute of Space Research - INPE for a station located in the municipality of Arcoverde, Pernambuco State, located upstream.

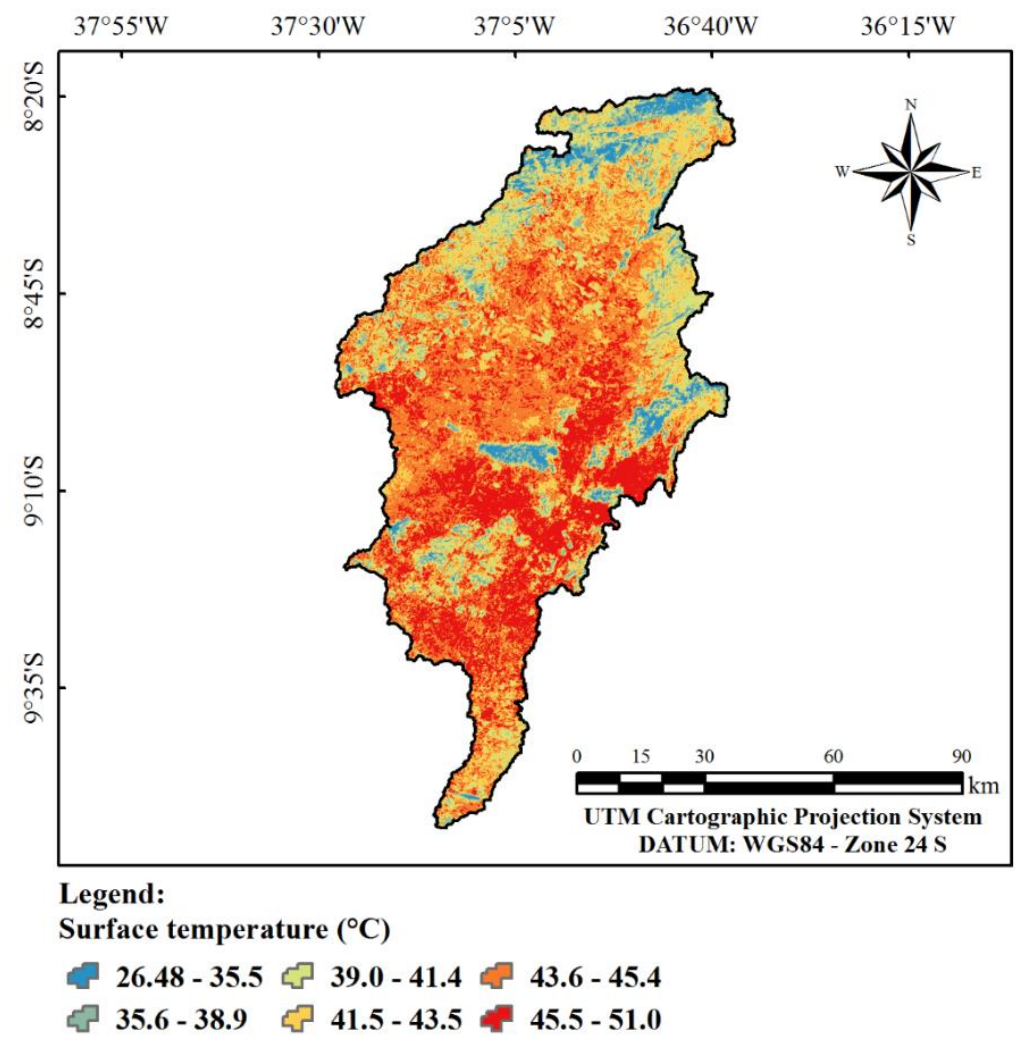

Figure 3 - Thematic map of the spatial distribution of surface temperature $\left({ }^{\circ} \mathrm{C}\right)$ in the Ipanema River Basin on the day of passage of the Landsat 8 (14 November 2015).

The surface temperature was determinant in the final result of the radiation balance, its computation made it possible to determine the long wave radiation emitted by the same (Silva et al., 2005; Oliveira et al., 2012; Bezerra et al., 2014). Therefore, the determination of the surface radiation balance $\left(\mathrm{R}_{\mathrm{n}}\right)$ has been shown to be related to the albedo behavior and the surface temperature, that is, the previously analyzed parameters can affect the radiation balance in the Ipanema River basin. Table 2 shows the average instantaneous variables used to estimate the radiation balance.

These variables are essential for $R_{n}$ quantification. 
Table 2 - Average instantaneous variables required to estimate the instantaneous surface radiation balance $\left(\mathrm{R}_{\mathrm{n}}, \mathrm{W} \mathrm{m}^{-2}\right)$.

\begin{tabular}{cccccc}
\hline \multirow{2}{*}{$\begin{array}{c}\text { Landsat } \\
\text { Satellite }\end{array}$} & Date of image & \multicolumn{4}{c}{ Mean instantaneous variables for $\mathbf{R}_{\mathbf{n}}$} \\
\cline { 3 - 6 } & & $\boldsymbol{\varepsilon}_{\mathbf{0}}$ & $\mathbf{R}_{\text {ol emit } \uparrow}$ & $\mathbf{R}_{\text {ol atm } \uparrow}$ & $\mathbf{R}_{\text {s inc } \downarrow}$ \\
\hline 8 OLI/TIRS & $11 / 14 / 2015$ & 0.953 & 535.7 & 323.2 & 583.5 \\
\hline
\end{tabular}

It is observed in Figure 4 that some areas of the studied scene presented $R_{n}$ of smaller magnitude in regions of bare soil or with less vegetated area. In places marked by denser vegetation, the magnitude of Rn was higher. These results corroborate with those obtained by Oliveira et al. (2015), in the Tapacurá river basin, Pernambuco State, where the $\mathrm{R}_{\mathrm{n}}$ presented values higher than $500 \mathrm{~W} \mathrm{~m}^{-2}$ in the dry season. Similarly, Silva et al. (2005), in a study carried out in the State of Paraíba, observed values of $\mathrm{R}_{\mathrm{n}}$ less expressive in the Caatinga area compared to areas marked by the presence of irrigated areas and water bodies, evidencing that this is the spatial distribution trend of $R_{n}$.

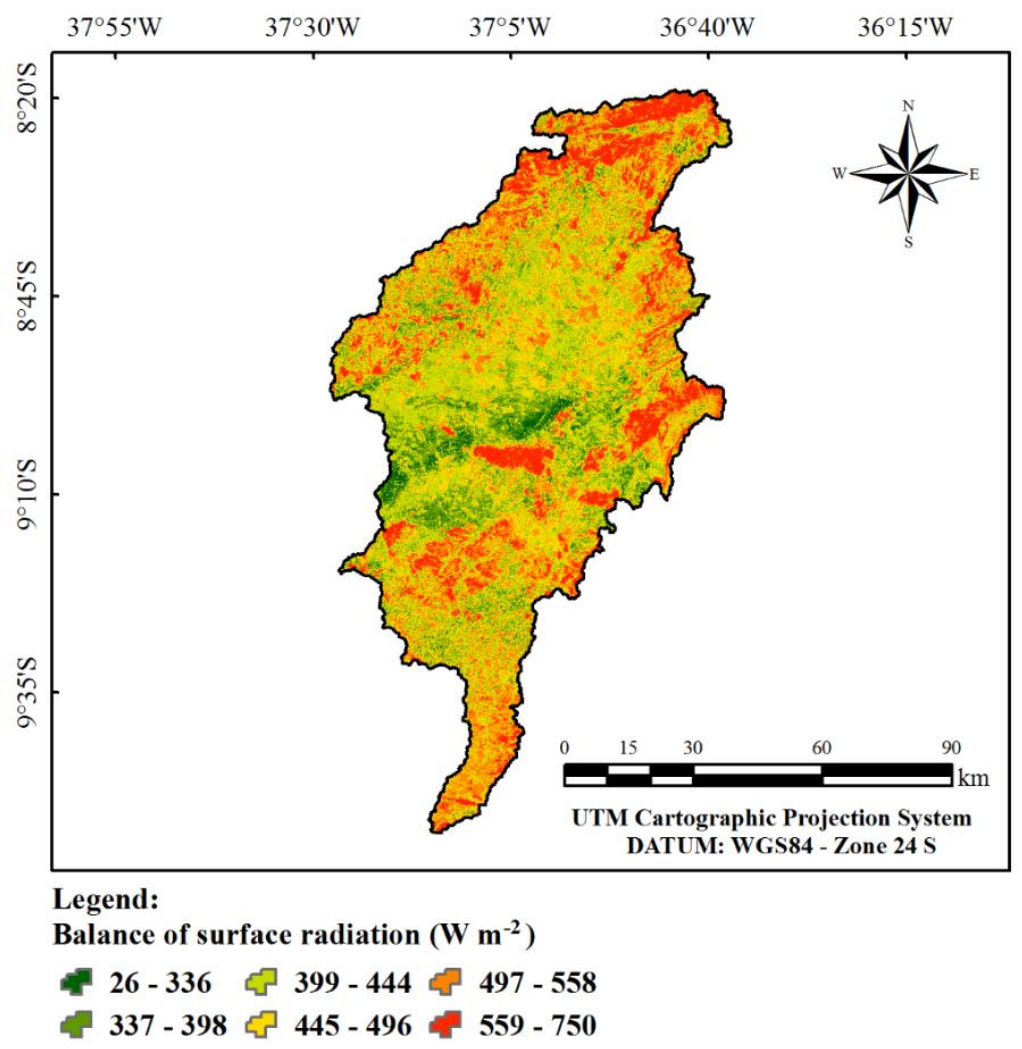

Figure 4 - Thematic map of the spatial distribution of the surface radiation balance $\left(\mathrm{W} \mathrm{m}^{-2}\right)$ in the Ipanema River Basin on the day of passage of the Landsat 8 (14 November 2015).

Table 3 shows the statistical summary of the data discussed. It is possible to verify that the mean value of $\mathrm{Rn}$ for the basin was $468 \mathrm{~W} \mathrm{~m}^{-2}$, with a maximum of $750 \mathrm{~W} \mathrm{~m}^{-2}$ in densely vegetated places. In comparison with the other parameters, the $\mathrm{R}_{\mathrm{n}}$ had the highest standard deviation around the mean, which may be related to the natural variation of $R_{n}$ as a function of the spectral characteristics of the targets, since the difference between the minimum valueo $\left(26 \mathrm{~W} \mathrm{~m}^{-2}\right)$ and maximum $\left(750 \mathrm{~W} \mathrm{~m}^{-2}\right)$ was quite pronounced. 
Table 3 - Statistical analysis of the spatial-temporal distribution of the biophysical parameters: surface albedo ( $\left.\alpha_{\text {sup }}\right)$, surface temperature $\left(\mathrm{T}_{\text {sup }},{ }^{\circ} \mathrm{C}\right)$ and surface radiation balance $\left(\mathrm{R}_{\mathrm{n}}, \mathrm{W} \mathrm{m}^{-2}\right)$.

\begin{tabular}{|c|c|c|c|c|c|c|c|c|}
\hline \multirow{2}{*}{$\begin{array}{l}\text { Landsat } \\
\text { Satellite }\end{array}$} & \multirow{2}{*}{ Date of image } & \multicolumn{7}{|c|}{ Surface albedo $\left(\boldsymbol{\alpha}_{\text {sup }}\right)$} \\
\hline & & Min. & Max. & Mean & Median & Moda & SD & $\mathbf{C V}$ \\
\hline \multirow{5}{*}{8 OLI/TIRS } & \multirow{5}{*}{$11 / 14 / 2015$} & 0.04 & 0.5 & 0.25 & 0.24 & 0.22 & 0.06 & 0.24 \\
\hline & & \multicolumn{7}{|c|}{ Surface temperature $\left(\mathbf{T}_{\text {sup, }},{ }^{\circ} \mathbf{C}\right)$} \\
\hline & & 26.48 & 51.03 & 43.02 & 42.85 & 44.1 & 3.12 & 0.07 \\
\hline & & \multicolumn{7}{|c|}{ Surface radiation balance $\left(R_{n}, W ~ m^{-2}\right)$} \\
\hline & & 26 & 750 & 468 & 476.78 & 465.81 & 71.9 & 0.15 \\
\hline
\end{tabular}

The albedo values were consistent with the literature, more expressive on bare soil and lower in the water bodies. This parameter confirmed, through its monitoring, to be important in the interpretation of studies of environmental changes in the semiarid, caused mainly by anthropic actions. Thus, the observed changes in surface temperature patterns in the spatial analysis corresponded to the same pattern found in the albedo. The balance of instantaneous radiation showed sensitivity to the different land uses, being effective due to the lack of field measurement data. The $R_{n}$ was directly related to the spatial patterns of the albedo and the surface temperature. The highest values of $R_{n}$ were represented by the lowest values of albedo. Silva et al. (2011), observed similar behavior in the spatial patterns of the same biophysical parameters.

The results obtained, in general, corroborate with those present in the literature and show typical spectral behavior of targets that integrate land use and occupation classes in the semiarid region during the dry season.

\section{Conclusions}

The analysis using the SEBAL algorithm showed great potential in the estimation of the radioactive balance, allowing a consistent way to monitor the different land uses and occupations around the Ipanema River Basin, concluding that in the areas of the basin with high values of albedo and also surface temperature, are indications of areas in the process of degradation or already degraded.

Therefore, actions that aim to mitigate this process must be taken, so that this process does not become permanent and that there are not so many losses during the dry season, avoiding mainly future processes of desertification.

\section{Acknowledgments}

The authors wish to thank the Federal Rural University of Pernambuco (UFRPE) and the Graduate Program in Agricultural Engineering (PGEA) for the opportunity to be part of the student body, as well as the guiding teachers; Coordination for the Improvement of Higher Education Personnel (CAPES) and Foundation for Science and Technology (FACEPE) for for research grants; Pernambuco State Water and Climate Agency (APAC) and the National Meteorological Institute (INMET) for the availability of the meteorological data for conducting the research.

\section{References}

Allen, R.G., Tasumi, M., Trezza, R., 2007. SatelliteBased energy balance for mapping evapotranspiration with internalized calibration (METRIC) - Model. Journal of Irrigation and Drainage Engineering 133, 380-394.

Allen, R., Tasumi, M., Trezza, R., Waters, R., Bastiaanssen, W., 2002. SEBAL: Surface Energy Balance Algorithms for Land, Idaho implementation. Idaho: Waters Consulting: University of Idaho: Water Watch, Inc. (Advanced Training and Users Manual, version 1.0).

APAC. Agência Pernambucana de Águas e Clima, 2017. Disponível:

http://www.apac.pe.gov.br/pagina.php?page_id=5\& subpage_id=16. Accesso: 12 jul. 2017.

Bastiaanssen, W.G.M., 2000. SEBAL - Based Sensible and Latent Heat Fluxes in the Irrigated Gediz Basin, Turkey. Journal of Hydrology 229, 87-100.

Bastiaanssen, W.G.M., Noordman, E.J.M., Pelgrum, H., Davids, G., Thoreson, B.P., Allen, R.G., 2005. SEBAL model with remotely sensed data to improve 
water resources management under actual field conditions. Journal of Irrigation and Drainage Engineering 131, 85-93.

Bastiaanssen, W.G.M., Pelgrum, H., Wang, J., Ma, Y., Moreno, J.F., Roerink, G.J., Van Der Wal, T., 1998. A remote sensing surface energy balance algorithm for land (SEBAL). Part 2: Validation. Journal of Hydrology 212-213, 213-229.

Bezerra, J.M., Moura, G.B.A., Silva, B.B., Lopes, P.M.O., Silva, E.F.F., 2014. Parâmetros biofísicos obtidos por sensoriamento remoto em região semiárida do estado do Rio Grande do Norte, Brasil ${ }^{1}$. Revista Brasileira de Engenharia Agrícola e Ambiental 18, 73-84.

Chander, G., Markhan, B., 2003. Revised Landsat 5 TM radiometric calibration procedures and post calibration dynamic ranges. IEEE Transactions on Geosciences and Remote Sensing 41, 2674-2677.

Cunha, J.E.B.L., Rufino, I.A.A., Silva, B.B., Chaves, I.B., 2012. Dinâmica da cobertura vegetal para a Bacia de São João do Rio do Peixe, PB, utilizandose sensoriamento remoto. Revista Brasileira de Engenharia Agrícola e Ambiental, 16, 539-548.

Garrison, J.D., Adler, G.P., 1990. Estimation of precipitable water over the United State for application to the division of solar radiation into its direct and diffuse components. Solar Energy 44, 225 241.
Iqbal, M., 1983. An Introduction to Solar Radiation. Academic Press., London.

Oliveira, L.M.M., Montenegro, S.M.G.L., Antonino, A.C.D., Silva, B.B., Machado, C.C.C., Galvíncio, J.D., 2012. Análise quantitativa de parâmetros biofísicos de bacia hidrográfica obtidos por sensoriamento remoto. Pesquisa Agropecuária Brasileira 47, 1209-1217.

Oliveira, L.M.M., Montenegro, S.M.G.L., Silva, B.B., Moura, A.E.S.S., 2015. Balanço de radiação por sensoriamento remoto em bacia hidrográfica da zona da mata nordestina. Revista Brasileira de Meteorologia 30, 16-28.

Silva, B.B.D., Braga, A.C., Braga, C.C., Oliveira, L.M., Montenegro, S.M., Barbosa Junior, B., 2016. Procedures for calculation of the albedo with OLILandsat 8 images: Application to the Brazilian semiarid. Revista Brasileira de Engenharia Agrícola e Ambiental 20, 3-8.

Silva, B.B., Lopes, G.M., Azevedo, P.V., 2005. Balanço de radiação em áreas irrigadas utilizando imagens Landsat 5 - TM. Revista Brasileira de Meteorologia 20, 243-252.

Silva, B.B., Silva, S.T.A., Gomes, H.B., 2011. Balanço de radiação no perímetro irrigado São Gonçalo - PB mediante imagens Orbitais. Revista Caatinga 24, 143-152. 